\title{
Information Brief on Green Power Marketing
}

Second Edition

\author{
Prepared by \\ Blair Swezey \\ Ashley Houston \\ National Renewable Energy Laboratory
}




\section{What's New in this Edition}

\section{Utility Green Pricing Programs}

- New and updated information on programs offered by Arizona Public Service, Central and South West Services, Colorado Springs Utilities, Cooperative Power, Dakota Electric, Fort Collins Light \& Power, Lincoln Electric System, Nevada Power Company, Public Service Company of Colorado, Sacramento Municipal Utility District, Tennessee Valley Authority, and Wisconsin Electric Power Company.

\section{Retail Access Pilot Programs}

- New and updated information on retail pilot programs in the Pacific Northwest, including those being conducted by Clark Public Utilities, Pacific Power, Portland General Electric, Puget Sound Energy, and Washington Water Power.

Green Power Marketers

- New and updated information on green power marketers, including Electric Lite, Enron Energy Services, Foresight Energy Company, and Working Assets Green Power.

\section{Other Market News}

- New information on other green power-related activities, including the Renewable Energy Alliance, the Natural Resources Defense Council, the Corporation for Solar Technology and Renewable Resources, and the National Association of Attorneys General.

\section{State Restructuring Policies.}

- A new section that summarizes renewables policies adopted in state restructuring legislation. 


\section{Executive Summary}

\section{Utility Green Pricing Programs}

- More than 30 utilities have either developed or are in the process of developing green pricing programs for their customers. Utilities with established programs note high customer retention rates, indicating high rates of customer satisfaction.

- The majority of green pricing options have been offered to residential and small commercial customers. Only a handful of utilities are attempting to market green power to larger wholesale or industrial customers.

- Customer response to utility green pricing programs has been as high as 3.1\% (in Traverse City, Michigan) but is generally $1 \%$ or less. The seemingly low response rates can be attributed partly to the experimental nature of many programs, with utility-imposed subscription limits, and the singular nature of most green product offerings.

- Utilities are beginning to design programs to better reflect the types of services that might be offered to customers in a competitive market, e.g., grid-based or project-specific programs that allow customers to purchase as much as $100 \%$ of their electricity from renewable sources.

\section{Retail Access Pilot Programs}

- Early indications from the retail access pilot programs in which green power options have been offered are that the potential demand for green power products and services in a more competitive electric marketplace is significant, particularly among residential customers. For example, in the Massachusetts Electric pilot, nearly one-third of residential pilot participants chose an "environmentally preferable" service provider. Several new pilot programs are scheduled to begin in the Northwest during 1998.

\section{Other Market News}

- A handful of power marketers, or energy service providers (ESPs), have announced plans to market green power when retail electricity markets open to competition. Marketing activity has already begun in eamest in California, where retail choice for all customers is scheduled to begin by March 31,1998 . Several companies have announced green power products that will contain at least $50 \%$ renewables content.

- Although utility green pricing programs have offered almost exclusively new, renewables-based electricity, pilot program suppliers in Massachusetts and New Hampshire included a number of nonrenewables-based alternatives in their green service options, such as energy efficiency programs, retirement of emission credits, and donations to environmental groups. This experience highlighted a number of important issues related to selling green power in competitive markets, such as verifying "green" power claims, the proportion of renewables 
content, and educating and informing customers about competitive market choices. A number of groups are working actively to address these issues.

\section{State Restructuring Policies}

- Ten states have passed electric power industry restructuring legislation and seven other states have issued regulatory orders. Ten of these 17 states have included some type of policy consideration, such as a renewables portfolio standard or a system benefits charge, to help assure that renewables remain viable during the transition to competition. 


\section{Introduction}

The essence of green power marketing is to provide market-based choices for electricity consumers to purchase power from environmentally preferred sources. Green power marketing has the potential to expand domestic markets for renewable energy technologies by fostering greater availability of renewable electric service options in retail markets. Although renewables development has previously been limited by cost considerations, customer choice allows consumer preferences for cleaner energy sources to be reflected in market transactions. In survey after survey, customers have expressed a willingness to pay more, if necessary, for cleaner energy sources.

Green pricing is an optional utility service that allows customers to support a greater level of utility company investment in renewable energy technologies. Participating customers pay a premium on their electric bill to cover the incremental cost of the additional renewable energy. Many utilities are offering green pricing to build customer loyalty and expand business lines and expertise in advance of electric market competition. To date, more than 30 utilities have either implemented or announced plans to offer a green pricing option.

The more general concept of green power marketing refers to the selling of green power in the competitive marketplace, in which multiple suppliers and service offerings exist. Retail access pilot programs are providing opportunities for power marketers and customer aggregators to test green power offerings in competitive markets. Early indications from some pilot programs are that the potential demand for green power products and services in a more competitive electric marketplace is very large. In Massachusetts, nearly one-third of residential pilot participants chose an "environmentally preferable" service provider, and in New Hampshire, $37 \%$ of customer participants polled said they were either "strongly influenced" or "moderately influenced" by the environmental message or image of their chosen supplier.

However, these pilot programs have also highlighted a number of issues related to selling green power in competitive markets, such as verifying "green" power claims and educating and informing customers about environmentally preferable competitive market choices. As more states move toward providing customer choice in electricity services, a number of activities are being pursued to help address product credibility and other market issues. Some states are also adopting policies to support a minimum amount of renewables development during the transition to competitive markets.

This document is the second in a series of information briefs on green power marketing activity in the United States. It includes descriptions of utility green pricing programs, green power marketing activity, retail access legislation and pilot programs, and other data and information supporting the development of green power markets. 


\section{Utility Green Pricing Programs}

Green pricing is an optional utility service offered to customers who want to increase the utility's reliance on renewable energy. Participating customers pay a premium on their electric bill to cover the incremental cost of the additional renewable energy.

To date, more than 30 utilities have developed or are in the process of developing green pricing programs for their customers.

\begin{tabular}{ll}
\multicolumn{1}{c}{ Utilities } & Publicly Owned Utilities \\
Arizona Public Service & City of Aspen \\
Central and Southwest Services & City of Austin \\
Detroit Edison & Colorado Springs Utilities \\
Florida Power and Light & Fort Collins Light \& Power \\
Gulf Power Company & Gainesville Regional Utilities \\
Hawaiian Electric Company & Lincoln Electric System \\
Indianapolis Power and Light & City of Tallahassee \\
Madison Gas \& Electric & Traverse City Light and Power \\
Nevada Power Company & Sacramento Municipal Utility District \\
New York State Electric and Gas & Rural Electric Cooperatives \\
Northern States Power & Cooperative Power \\
Portland General Electric & Dakota Electric Association \\
Public Service Company of Colorado & Holy Cross Electric Association \\
West Texas Utilities & United Power Association \\
Wisconsin Electric Power Company & \\
Wisconsin Public Service Corporation & Other \\
& Bonneville Power Administration
\end{tabular}

Note: Utilities in bold denote programs that have actually resulted in the installation of new renewables capacity funded by green pricing subscriptions or contributions. 


\section{Types of Green Pricing Programs}

There are three basic types of green pricing programs:

Contribution program - Customers can contribute to a utility-managed fund for renewable project development. All of the projects developed under contribution programs have used photovoltaics (PV) and have been relatively small, with the exception of the Sacramento Municipal Utility District, which has developed a total of 1.5 megawatts (MW) of PV since 1993 through its PV Pioneers green pricing program.

Capacity-based program - Customers can choose to purchase a fixed block of their electric capacity requirements from renewables. To date, capacity-based programs have offered PV exclusively, in rooftop or localized applications. Monthly premiums range from $\$ 2.50$ to $\$ 8.50$ per 100 watts (W) of capacity.

Energy-based program - Customers can choose to purchase a fixed block or percentage of their electric energy requirements from renewables. This type of program generally offers renewable energy sources that are most competitive with bulk power generation. For example, 10 of 13 such programs either under way or planned will use wind power. Nevertheless, the actual or proposed price premiums vary from about $1.5 \phi /$ kilowatt-hour $(\mathrm{kWh})$ to as much as $6 \phi / \mathrm{kWh}$.

Tables $1-3$ summarize the different utility green pricing programs. 
Table 1 - Contribution Programs

\begin{tabular}{||l|c|c|l||}
\hline Utility & Technology & Size & \multicolumn{1}{|c||}{ Notes } \\
\hline \hline Florida Power and Light & PV & $10 \mathrm{~kW}$ & Utility site \\
\hline Gainesville Regional Utilities & PV & $10 \mathrm{~kW}$ & Demonstration project on utility property \\
\hline Gulf Power & PV & N/A & Schools-based projects \\
\hline Hawaii Electric Company & PV & $20 \mathrm{~kW}$ & Schools-based projects \\
\hline $\begin{array}{l}\text { Public Service Company of } \\
\text { Colorado }\end{array}$ & PV & $15 \mathrm{~kW}$ & Several small off-grid projects \\
\hline $\begin{array}{l}\text { New York State Electric and } \\
\text { Gas }\end{array}$ & PV & $\approx 10 \mathrm{~kW}$ & $\begin{array}{l}\text { Limited number of residential rooftop } \\
\text { systems }\end{array}$ \\
\hline $\begin{array}{l}\text { Sacramento Municipal Utility } \\
\text { District }\end{array}$ & PV & $1,500 \mathrm{~kW}$ & $\begin{array}{l}\text { PV Pioneers program; also, community- } \\
\text { based PV program }\end{array}$ \\
\hline \hline City of Tallahassee & PV & $10 \mathrm{~kW}$ & Public building \\
\hline \hline Wisconsin Public Service & PV & $36 \mathrm{~kW}$ & $\begin{array}{l}\text { Three schools-based projects with three } \\
\text { more planned. Also offers residential } \\
\text { rooftop systems. }\end{array}$ \\
\hline \hline
\end{tabular}

Table 2 - Capacity-Based Programs

\begin{tabular}{|c|c|c|c|}
\hline Utility & Size & Premium & Notes \\
\hline Arizona Public Service & $\begin{array}{l}82 \mathrm{~kW} \\
82 \mathrm{~kW}\end{array}$ & $\$ 3.00 / 100$ watts & $\begin{array}{l}\text { Centralized project on utility property; } \\
\text { first project was doubled in size to meet } \\
\text { demand, second project being } \\
\text { constructed }\end{array}$ \\
\hline City of Austin & N/A & $\$ 3.50 / 50$ watts & $\begin{array}{l}\text { Several commercial-scale projects, } \\
\text { depending on customer response }\end{array}$ \\
\hline Detroit Edison & $\begin{array}{l}28.4 \mathrm{~kW} \\
26.4 \mathrm{~kW}\end{array}$ & $\$ 6.59 / 100$ watts & $\begin{array}{l}\text { Two centralized projects on utility } \\
\text { property; other projects are being } \\
\text { planned }\end{array}$ \\
\hline Northern States Power & $34 \mathrm{~kW}$ & $\$ 2.50 / 100$ watts & $17,2-k W$ residential systems \\
\hline Wisconsin Public Service & N/A & $\$ 8.50 / 100$ watts & $\begin{array}{l}\text { As many as } 26 \text { residential rooftop } \\
\text { systems }\end{array}$ \\
\hline
\end{tabular}


Table 3 - Energy-Based Programs

\begin{tabular}{|c|c|c|c|c|}
\hline Utility & Technology & Size & Premium & Notes \\
\hline $\begin{array}{l}\text { Bonneville Power } \\
\text { Administration }\end{array}$ & $\begin{array}{l}\text { Wind/ } \\
\text { Geothermal }\end{array}$ & N/A & $1.0 \phi / \mathrm{kWh}$ & $\begin{array}{l}\text { Program for larger } \\
\text { customers }\end{array}$ \\
\hline Cooperative Power & Wind & 1.3-1.5 MW & $2.0 \phi / \mathrm{kWh}$ & $\begin{array}{l}\text { Will contract from new } \\
\text { project for its distribution } \\
\text { cooperatives }\end{array}$ \\
\hline Colorado Springs Utilities & Wind & $0.5 \mathrm{MW}$ & $3.0 \phi / \mathrm{kWh}$ & $\begin{array}{l}\text { Wholesale purchase from } \\
\text { PSCo }\end{array}$ \\
\hline $\begin{array}{l}\text { Dakota Electric } \\
\text { Association }\end{array}$ & Wind & $0.8 \mathrm{MW}$ & $2.0 \phi / \mathrm{kWh}$ & $\begin{array}{l}\text { Wholesale purchase from } \\
\text { Cooperative Power }\end{array}$ \\
\hline $\begin{array}{l}\text { Fort Collins Light and } \\
\text { Power }\end{array}$ & Wind & $1.5 \mathrm{MW}$ & $2.0 \phi / \mathrm{kWh}$ & Two 750-kW turbines \\
\hline $\begin{array}{l}\text { Holy Cross Electric } \\
\text { Association }\end{array}$ & Wind & $2.75 \mathrm{MW}$ & $2.5 \phi / \mathrm{kWh}$ & $\begin{array}{l}\text { Wholesale purchase from } \\
\text { PSCo }\end{array}$ \\
\hline Lincoln Electric System & Wind & $750 \mathrm{~kW}$ & $6.0 \phi / \mathrm{kWh}$ & New project \\
\hline $\begin{array}{l}\text { Madison Gas and } \\
\text { Electric }\end{array}$ & Wind & $11.25 \mathrm{MW}$ & $4-5 \phi / \mathrm{kWh}$ & $\begin{array}{l}\text { New project; regulatory filing } \\
\text { pending }\end{array}$ \\
\hline Portland General Electric & Wind & $5.0 \mathrm{MW}$ & $1.0 \phi / \mathrm{kWh}$ & $\begin{array}{l}\text { Program for larger } \\
\text { wholesale customers }\end{array}$ \\
\hline $\begin{array}{l}\text { Public Service Company } \\
\text { of Colorado }\end{array}$ & Wind & $10 \mathrm{MW}$ & $2.5 \phi / \mathrm{kWh}$ & $\begin{array}{l}\text { Committed to } 10 \mathrm{MW} \text { in } \\
\text { Phase } 1\end{array}$ \\
\hline $\begin{array}{l}\text { Sacramento Municipal } \\
\text { Utility District }\end{array}$ & Various & N/A & $1.0 \phi / \mathrm{kWh}$ & $\begin{array}{l}\text { From "new grid-based } \\
\text { renewable resources" }\end{array}$ \\
\hline $\begin{array}{l}\text { Traverse City Light and } \\
\text { Power }\end{array}$ & Wind & $0.6 \mathrm{MW}$ & $1.58 \phi / \mathrm{kWh}$ & Built dedicated wind turbine \\
\hline United Power Association & Wind & 一 & - & $\begin{array}{l}\text { In negotiations with NSP for } \\
\text { wind energy purchase }\end{array}$ \\
\hline West Texas Utilities & Small Hydro & $1.2 \mathrm{MW}$ & $2.0 \phi / \mathrm{kWh}$ & Existing small hydro \\
\hline $\begin{array}{l}\text { Wisconsin Electric Power } \\
\text { Company }\end{array}$ & Wood/Hydro & $5.0 \mathrm{MW}$ & $2.04 \phi / \mathrm{kWh}$ & $\begin{array}{l}\text { Purchasing renewables in } \\
\text { the wholesale market }\end{array}$ \\
\hline
\end{tabular}




\section{Green Pricing Program Summaries}

Arizona Public Service-APS established a solar tariff to help develop as much as $400 \mathrm{~kW}$ of "centralized photovoltaic systems" for its Solar Partners program. The power is being sold in 100watt capacity blocks at $\$ 3.00 / \mathrm{block} / \mathrm{month}$. The program costs are being partially subsidized with a grant from the Utility PhotoVoltaic Group (UPVG). The program is open to all APS customers.

The first project was built in Flagstaff. The initial customer response well exceeded the utility's target and the project was expanded from $41 \mathrm{~kW}$ to $82 \mathrm{~kW}$. APS announced plans to expand the program statewide, including a second $82-\mathrm{kW}$ PV project to be built at the site of an existing power plant in Tempe. APS has proposed a program for industrial and commercial customers, which is being reviewed by the Arizona Corporation Commission.

City of Aspen-As a full-requirements customer of the Municipal Energy Agency of Nebraska (MEAN), the City of Aspen Municipal Electric System asked MEAN to talk with Public Service Company of Colorado (PSCo) regarding a possible wind energy purchase (see PSCo summary). The Community Office for Resource Efficiency (CORE) is helping Aspen develop a green pricing program for its customers. No definitive commitment has been made.

City of Austin-The City of Austin Electric Utility Department offers customers the opportunity to purchase 50-watt increments of power from photovoltaic systems to be installed in three types of applications: shade structures for parking lots, ballast-mounted arrays, and flat-topped commercial buildings. The monthly premium is $\$ 3.50$ per 50 -watt block. The utility changed the premium from $\$ 7.00$ per month for 100 watts because some customers felt that the original premium was too high, and to make the program accessible to a larger customer base. The Austin program was developed under the UPVG TEAM-UP (Technology Experience to Accelerate Markets in Utility Photovoltaics) PV Friendly Pricing program. As of May 1997, the program had about 50 customer participants.

Bonneville Power Administration-BPA developed a green power product consisting of a portfolio of four renewable projects (two wind and two geothermal) to market to its wholesale customers. Among the key selling points of the package are a 20-year guaranteed price stream, the provision of transmission and load "shaping" services, and the ability to buy as much or as little of the product as desired.

The first utility customer to sign up for the BPA service was Salem Electric Cooperative, which will purchase 7 average megawatts (aMW) of capacity at a price of $3.5 \mathrm{~d} / \mathrm{kWh}$ (a premium of $1.0 \mathrm{~d} / \mathrm{kWh}$ ). BPA recently confirmed its purchase of $15 \mathrm{MW}$ of capacity from PacifiCorp's 41.4-MW Wyoming wind project to serve the Salem load.

BPA also signed an agreement with the Environmental Resources Trust (ERT), an independent, nonprofit organization founded with the help of the Environmental Defense Fund, to broker BPA power products that have environmental benefits. The products include incremental power generated from federal hydro facilities during fish recovery operations, power generated from renewable energy projects, and power from instream flow improvements enabled by ERT water purchases. Acting as 
a broker, ERT will offer this power to BPA's wholesale customers whose alternative sources are more expensive or who are willing to pay more for environmentally beneficial energy. Proceeds from the sales will be invested in fish and wildlife and other environmental projects.

Central and South West Corporation-CSW has developed the "Clear Choice" green pricing pilot program. Residential customers can sign up at three levels. For $\$ 5, \$ 10$ or $\$ 20$ more a month on their electric bill, customers choose to have $250 \mathrm{kWh}, 500 \mathrm{kWh}$, or $1,000 \mathrm{kWh}$, respectively, of traditional generation replaced by hydropower electricity produced in Texas. The pilot program was introduced in San Angelo, Texas, in October 1997 and plans are underway to offer the Clear Choice program throughout the CSW system in 1999 (see also West Texas Utilities).

The development of the green pricing program is a direct result of a Deliberative Polling ${ }^{\mathrm{TM}}$ process by which a representative sample of customers overwhelmingly supported further development of renewable resources. More than $80 \%$ of customers indicated a willingness to pay at least $\$ 1.00$ more per month for the companies to acquire more renewable resources. Some customers indicated a willingness to pay as much as $\$ 10.00$ more per month.

Colorado Springs Utilities-Colorado Springs Utilities has signed a contract with Public Service Company of Colorado for the purchase of $500 \mathrm{~kW}$ of wind power through PSCo's WindSource program. Utility surveys indicated that some customers want the utility to pursue clean energy for environmental reasons and to gain experience with new technologies. In March 1997, the city council approved the development of a wind power plan. Colorado Springs has started marketing the program, which will charge a premium of $\$ 3.00$ per $100-\mathrm{kWh}$ block of wind energy, and is actively seeking residential and commercial subscribers with the intent of supplying wind power to participating customers beginning in April.

Cooperative Power- $\mathrm{CP}$, a generating and transmission cooperative that provides electricity to 17 member distribution cooperatives in southern and western Minnesota, announced a program to procure wind energy for its distribution members to sell in green pricing programs. With the program almost fully subscribed, CP plans to contract for 1.3-1.5 MW of new wind power. As of February 1998, 11 member coops had agreed to participate, and more than thirty-six hundred, 100$\mathrm{kWh}$ blocks had been subscribed. CP recently lowered its wind power premium from a range of $\$ 3-\$ 4$ per block to $\$ 2$ per block because of the availability of a state production incentive. CP expects to sign a contract with the wind power provider in March and hopes that the project, to be located in southwestern Minnesota, will begin operating in November.

Dakota Electric Association-The Minnesota PUC approved a tariff filing by Dakota Electric to offer its customers a wind energy purchase option. The power will be supplied by Cooperative Power, Dakota Electric's wholesale supplier. Under the program, customers can purchase 100-kWh blocks of wind-generated electricity at a proposed rate premium of $\$ 2$ per block. A 12-month subscription commitment is required. 
Detroit Edison-In 1996, Detroit Edison developed a 28.4-kW, centrally located PV demonstration facility under a green pricing program in which customers pay for 100-watt blocks of capacity, rather than for the electricity generated. The monthly premium is $\$ 6.59$ per block. The project was costshared by UPVG and is fully subscribed with 195 participating customers and a waiting list of 40 customers. On average, participants have increased their monthly bills by $\$ 10.75(17.2 \%)$ with an average subscription of 145 watts of PV capacity.

Given continued customer interest, the utility plans to site three additional projects and to develop a schools-based program for commercial customer sponsors. The Michigan Public Service Commission (PSC) formally approved an expansion of the program in July 1997.

In October 1997, Detroit Edison dedicated a second solar electric facility $(26.4 \mathrm{~kW})$. The utility also expanded the program to include commercial customers. To date, six area businesses have committed to participate in a new program that will donate solar-generated electricity to Southeastern Michigan school districts. Participating school districts will also receive a two-week solar and renewable energy curriculum.

Detroit Edison was the winning bidder of the Maryland Energy Administration's RFP for installation of solar power systems at as many as 10 Maryland schools. Contributions will be solicited from Maryland citizens and businesses to help pay for the systems.

Florida Power and Light-Pursuant to a settlement agreement with the Legal Environmental Assistance Foundation, FP\&L will develop a green pricing program to support construction of PV systems. FP\&L plans to develop a 10-kW PV unit at one of its power plants, using bill inserts and direct mailings to solicit customers for the program. Customers will be able to designate specific dollar contributions with their monthly utility bill.

Fort Collins Light and Power-Approximately 700 residential and small-business customers have subscribed to a wind energy pilot program that offers wind energy at a premium of $2.0 \$ / \mathrm{kWh}$. The Colorado utility offered to contract for as many as three wind turbines, with each turbine commitment requiring 350 subscribers. With the 700 subscribers, Fort Collins will contract for power from two $750-\mathrm{kW}$ wind turbines. Residential subscribers will be required to purchase all of their power from wind, while commercial customers can purchase the wind power in 1,000-kWh blocks. The wind turbines, which will be installed in Medicine Bow, Wyoming, are scheduled to begin operating in May.

Gainesville Regional Utilities-On January 11, 1997, GRU completed a 10-kW PV demonstration project at the utility's Electric System Control Center. The project was funded by community donations and with grants from the Florida Energy Office and UPVG. GRU garnered community support for the project through its monthly customer bulletin and inserts in the local newspaper. More than 600 customers contributed to the project during a three-year period.

Gulf Power Company-Gulf Power implemented a schools-based solar program under which a variety of solar energy technologies will be installed at public schools using utility customer 
contributions leveraged with utility funding. The program seeks to offset conventionally generated electricity and to increase community awareness of renewable energy technologies.

Hawaiian Electric Company-HECO developed a program with a minimum goal of installing 20 $\mathrm{kW}$ of PV systems on public school facilities. Customers can make voluntary monthly fixed-dollar or lump-sum contributions at any time. $\mathrm{HECO}$ will contribute additional funding (a total of $\$ 140,000$ for two years). As of April 1997, more than 1,200 customers had contributed to the program, representing about $0.35 \%$ of HECO customers system-wide.

Holy Cross Electric Association-Holy Cross, which serves the Roaring Fork Valley in Colorado, is marketing a program under which its customers can purchase 100-kWh blocks of wind energy at a rate premium of $2.5 \mathrm{k} / \mathrm{kWh}$. Holy Cross is a wholesale customer of PSCo and will purchase wind power from PSCo's Colorado wind project.

As of October 1997, the utility had garnered subscriptions from 850 residential and commercial customers for a total of 1,800,100-kWh blocks of wind power; enough to cover the first megawatt of a planned 2.75-MW purchase. Holy Cross reports that it will begin marketing a 750-kW block of wind power early in 1998 and an additional $1 \mathrm{MW}$ in the summer. CORE is assisting the utility with customer recruiment. (See PSCo Summary)

Indianapolis Power and Light-IPL filed a plan with the Indiana Utility Regulatory Commission that, if approved, would allow IPL to offer customers the opportunity to try three new pricing options, including a green power purchase option. The as-yet-unspecified green power would be sold at a premium and would be available to all residential customers and other customers with demand not exceeding $2,000 \mathrm{~kW}$.

Lincoln Electric System-Beginning in May 1998, LES will begin offering its retail customers an opportunity to purchase units of electric energy generated by a new, $750-\mathrm{kW}$ wind turbine to be constructed northeast of Lincoln. The power will be offered to customers in 100-kWh units at a price of $\$ 6$ per unit-an average Lincoln home uses about 1,000 kWh per month. Customers will begin paying for the project upon sign-up. Once customers have committed to a total of 1,000 units of participation, LES will proceed with the project, which could be operating by the summer of 1999.

Madison Gas and Electric-In October 1997, MGE announced that it plans to construct, own, and operate an 11.25-MW wind farm in eastern Wisconsin that will be offered for sale in 100-kWh blocks to residential and business customers. MGE expects the price premium to be approximately $\$ 4-\$ 5$ per block. The plans call for fifteen, $750-\mathrm{kW}$ turbines to be supplied by Northern Alternative Energy, a Midwestern wind developer. MGE expects to file for regulatory approval before the end of the year.

Nevada Power Company-On October 1, 1997, NPC asked the Nevada PUC to approve a program that would allow residential and commercial customers the choice to round up their monthly bill or designate a flat monthly contribution for the utility to develop PV systems. NPC proposes to 
construct as many as forty-six, 20-kW PV systems over a 10-year period and has committed to begin the program by purchasing two systems, one in 1998 and one in 1999.

New York State Electric and Gas Company-NYSEG, a participant in the TEAM-UP PV Friendly Pricing program, installed two residential PV systems in September 1996. Participating customers pay a subsidized premium that is capped at $\$ 10$ per month. The utility plans to install four additional residential systems, two by the end of 1997 and two more in the spring of 1998. Currently, NYSEG has no plans to expand the project beyond the research and development (R\&D) stage.

Northern States Power Company-NSP installed seventeen, 2-kW PV systems on residential rooftops for which participating customers must pay a $\$ 50$ monthly charge for five years, after which time, the homeowner can sign another five-year contract, purchase the system outright for $\$ 3,000$, or have NSP remove the system. After 10 years, the homeowner can purchase the system for one dollar. Excess electricity generated is fed back into the grid under a net-metering arrangement. More than 270 customers applied for the program in 1996, which was cost-shared with UPVG.

Portland General Electric-PGE is packaging power from two planned wind projects for sale to wholesale customers at a premium of about $1 \phi / \mathrm{kWh}$ above the regular rate. Under a contract with the utility, the City of Portland has agreed to purchase 11.25 million $\mathrm{kWh}$ (1.29 aMW) of the wind energy for five years, equivalent to $5 \%$ of its power. The wind energy costs will be blended with lower "market-based" rates; the resulting "blended rate" will still be lower than the city's former contract rate.

Public Service Company of Colorado-PSCo established one of the first green pricing contribution programs in 1994. Approximately 15,000 customers contribute to the Renewable Energy Trust either through fixed contributions or using a bill "round up" option. Through the Trust, PSCo has deployed about $15 \mathrm{~kW}$ of off-grid PV systems.

During 1997, PSCo added two new green pricing options for its customers. The WindSource program offers customers an option to subscribe for 100-kWh blocks of electricity from a new wind project at a rate premium of $2.5 \mathrm{c} / \mathrm{kWh}$. As of January $1998,9.6 \mathrm{MW}$ of wind energy had been subscribed by approximately 4,000 residential, business, and wholesale customers. Among the utilities that have expressed an intent to purchase wind energy from PSCo are Holy Cross Electric Association, Colorado Springs Utilities, and Municipal Energy Agency of Nebraska. PSCo plans to have the first $4.5 \mathrm{MW}$ of capacity installed and operating during the first half of 1998 at a site in northeastern Colorado.

PSCo's SolarSource program offers customer-sited PV systems at a subsidized system cost of $\$ 4.00 /$ watt. Initially, PSCo plans to make as many as 20 systems available.

Sacramento Municipal Utility District-Since 1993, SMUD has operated the PV Pioneers program under which customers can choose to pay a $\$ 4.00$ flat monthly fee (for 10 years) to have a 2-kW to 4-kW, grid-connected PV system installed on their rooftops. SMUD installs, operates, 
maintains, and owns the hardware. As of May 1997, 420 residential and 20 commercial systems had been installed. Although total installations have been limited to approximately 100 systems per year, SMUD receives approximately 1,000 new applicants annually.

In June 1997, SMUD announced a PV Pioneers II program, through which customers can purchase PV systems and sell excess electricity back to the utility. SMUD will "buy-down" half of the $\$ 17,000$ system cost.

Looking toward the competitive retail market in California, SMUD developed a new "green rate" that will allow its customers to obtain $100 \%$ of their electricity needs from renewable sources; SMUD already meets nearly half of its power needs with renewables. The Renewables Energy Option gives customers the option to buy all of their electricity from new grid-based renewable resources at a rate premium of $1.0 \mathrm{c} / \mathrm{kWh}$. Participating residential customers would see an average bill increase of $\$ 7.00$ per month. SMUD recently announced that it will purchase power from a planned 8.3-MW landfill gas plant- one of the first newly constructed renewables resources to supply power for this program. The Community Solar program allows customers to contribute $1.0 \mathrm{~d} / \mathrm{kWh}$ for the purchase and installation of photovoltaic systems on schools, churches, and other community facilities. As of September 1997, more than 1,100 customers had signed up for the program.

City of Tallahassee-Pursuant to a settlement agreement with the Legal Environmental Assistance Foundation, the City of Tallahassee is developing a green pricing program for constructing PV systems. Tallahassee will match customer contributions of as much as $\$ 250,000$ to install a $10-\mathrm{kW}$ solar PV system on or near a city building.

Tennessee Valley Authority-TVA has issued a request for proposals for green power that it hopes to deliver to customers beginning in 2002. The amount of green power purchased will depend on the level of customer interest expressed, but TVA estimates that it could purchase up to $300 \mathrm{MW}$. The RFP defines green power to include only solar, wind, biomass, and geothermal resources, and though existing resources will be considered, preference will be given to new resources.

Traverse City Light \& Power-Since 1996, Traverse City (Michigan) has operated a green pricing program for its residential and small cominercial customers under which a $600-\mathrm{kW}$ wind turbine was developed. Residential and commercial customers pay a $1.58 \mathrm{c} / \mathrm{kWh}$ premium to purchase $100 \%$ of their power from wind energy; the premium represents a $17 \%-25 \%$ increase in the average monthly bill. There are 145 residential and 26 commercial customer participants, representing $3.1 \%$ of the total customer base. An additional 79 customers are on a waiting list. As of May 1997, no customers had dropped out of the program.

United Power Association-UPA, a generation and transmission cooperative based in Elk River, Minnesota, is planning to offer a wind power product to its 12 member distribution cooperatives for sale to their customers. The wind power would be sold in 100-kWh blocks in a one-year test program. UPA is negotiating to buy the wind power from NSP. Some controversy has developed around the proposed program because the power will come from NSP wind projects that were 
mandated by the Minnesota legislature. Thus, no net additions of renewable resources would result from the UPA green pricing program.

West Texas Utilities-WTU, a regulated utility subsidiary of Central and South West Corporation, announced a pilot program to offer residential and small business customers in San Angelo, Texas, an option to purchase power from an existing 1.2-MW small hydro project. Participating customers will pay a premium of $2 \varnothing / \mathrm{kWh}$ for the renewable electricity and can subscribe for fixed monthly blocks of $250 \mathrm{kWh}, 500 \mathrm{kWh}$, or $1,000 \mathrm{kWh}$. WTU intends to offer power from new renewable energy sources in later phases; contracts are being negotiated to acquire additional renewable resources. (See CSW Summary)

Wisconsin Electric Power Company-Wisconsin Electric offers an optional renewable electricity service to residential, farm, and small commercial customers from sources procured by the utility in the wholesale power market. Customers can choose to receive $25 \%, 50 \%$, or $100 \%$ of their power from renewables at a premium of approximately $2.0 \notin / \mathrm{kWh}$. The renewable power provided for the first year of the project came from existing hydro and biomass projects. The utility will add landfill gas to the renewables mix for the second year, which will total as much as $5 \mathrm{MW}$ of renewables supply. As of May 1997, 5,500 customers were participating in the program with a dropout of only 100 customers. Wisconsin Electric believes that its program represents a good test of the forthcoming competitive market for green power services, which the company believes may represent as much as $10 \%$ of the future electricity market.

In 1996, Wisconsin Environmental Decade (WED) filed suit against the Wisconsin PSC to block implementation of Wisconsin Electric's green pricing program. WED alleged that the PSC violated state law in approving, without a hearing, the green rate premium. WED also challenged the lack of a competitive acquisition process for the renewable resources. Wisconsin Electric expects to reach a settlement in March.

Wisconsin Public Service Corporation-The WPS SolarWise for Schools program resulted in three 12-kW PV system installations at local high schools in 1996, with funding coming from a combination of 2,600 customer participants, the company's R\&D budget, and the UPVG TEAM-UP program. The average customer contribution is $\$ 1.70$ per month. WPS plans to add an additional contribution method and pursue commercial and industrial sponsorship. Three additional school projects were undertaken in 1997 and seven other schools will receive curriculum packages designed for students to study renewable energy resources.

WPS also offers a residential PV option under which as many as 26 homes will be eligible to receive systems. Participating customers pay a one-time installation fee and a monthly service charge that averages $\$ 17.00$. This program is also partially subsidized by UPVG. The utility has plans to develop a special green rate for new renewables (initially solar or wind) to be developed within the utility's territory. 


\section{Retail Access Pilot Programs}

Retail customer choice pilot programs are operating or planned in several states and utility service territories. The following is a short description of pilot programs that offer or will offer green power options.

Clark Public Utilities—Clark Public Utilities (Washington) announced a pilot program ("Powerful Choices") in which 6,200 customers ( $2 \%$ of the customer base) will be able to choose the source of the electricity they purchase. The four power supply options offered include: (1) the current mix, (2) power from the Bonneville Power Administration, (3) green power, and (4) a market-priced option. Under the 12-month pilot that starts in March 1998, customers can choose to purchase more than one type of power supply, with a minimum of $25 \%$ from each source. The green power will come from existing renewables resources supplied by PacifiCorp and may also include wind power from a project under development.

Massachusetts Electric-The MECo pilot is the first pilot to explicitly include green power options in the program design. MECo opened as much as 100 million $\mathrm{kWh}$ in four cities to competition; four companies were selected to provide "environmentally sensitive" or "green" service options. Green options included not only generation from renewable resources, but energy efficiency programs, retirement of emissions credits, and donations to environmental groups and projects as well. Overall, $31 \%$ of residential and $3 \%$ of small business participants chose one of the four green options offered.

New Hampshire-A statewide pilot program was ordered by the New Hampshire Legislature in June 1995 to determine the implications of retail competition in the electric industry. The pilot began in May 1996 and is scheduled to run through April 1998. Approximately $3 \%$ of each electric utility's peak load, or a total of about $50 \mathrm{MW}$ statewide, was made available to competition, for which more than 30 power suppliers registered and about 16 competed actively. Although six suppliers used green marketing themes to sell their product, most companies attempted to project an environmentally friendly image rather than substantively work towards the addition of renewable energy resources. Although market share data is not available, a survey of customer participants found that $37 \%$ were either "strongly influenced" or "moderately influenced" by the environmental message or image of their power supplier.

Pacific Power-Pacific Power, a retail utility subsidiary of PacifiCorp, filed a new program with the Oregon PUC that will enable residential and small commercial customers in Klamath County to select from a portfolio of electricity pricing options, including market-based pricing and renewable energy options. The pilot program, which is scheduled to run through June 1999, was developed to facilitate the transition to full competition.

One unique feature of the program is a credit of $0.2 \phi / \mathrm{kWh}$ for customers who choose renewable power resources such as solar, wind, or biomass. The renewables credit is being offered "to encourage the use of this important, but often more expensive power option." 
Other elements of the pilot will give large-use customers and all schools within its Oregon service territory-including both private and public elementary and secondary schools, colleges, universities, and professional schools - the ability to shop for their power supplies. Schools may participate at 100 percent of their electric load, and customers with demand greater than $5 \mathrm{MW}$ can participate for up to 50 percent of their load.

Portland General Electric-PGE will offer 50,000 residences and businesses (7.5\%) in four area communities the opportunity to choose their electricity provider beginning December 1, 1997. All large commercial and industrial customers will be able to buy as much as $50 \%$ of their electricity from competing providers. PGE expects the program to "deliver competitive prices and innovative products, such as the opportunity to buy electricity generated solely from renewable resources." The Oregon PUC has certified seven energy service providers, including Avista Energy, Inc., Duke Energy Trading \& Marketing, L.L.C., Electric Lite, Inc., Enron Power Marketing, Inc., Illinova Energy Partners, PacifiCorp, and PG\&E Energy Services. The ESPs will be required to "label" their electricity, disclosing to customers from what source(s) the electricity is generated. Of the seven ESPs, only Electric Lite has formally announced a green power offering.

Puget Sound Energy-The Washington Utilities and Transportation Commission approved a two-year customer choice pilot program for residential, commercial, and industrial customers of Puget Sound Energy. Approximately 85,000 customers (10\%) within the pilot program areas will be able to purchase power from other utilities, brokers, and marketers. Although the power suppliers have yet to be selected, Puget is working to inform and educate customers about green power options that may be offered.

Washington Water Power-The Washington Utilities and Transportation Commission approved a new pilot program, which will offer electricity service choices to 7,800 WWP customers (3\%). The pilot ("More Options for Power Service II" or "MOPS II") will run from May 1, 1998 through April 30, 2000 and will provide customers with energy service alternatives without having to change energy service providers. Customers will be able to choose between five energy service alternatives including a green resource rate. Under the green rate, participating customers will pay an incremental dollar amount per $\mathrm{kWh}$ consumption block to receive green power, which will include a choice of biomass and wind power projects. 


\section{Green Power Marketers}

In addition to utilities offering or developing green pricing programs, a number of companies have announced plans to sell green power in states where retail access will soon be available. Several of these marketers have also participated in retail access pilot programs in Massachusetts and New Hampshire. The following section provides information on these green power providers.

Automated Power Exchange-APX is developing a fully automated electricity exchange through which sellers and buyers can make power transactions in the Califomia electricity market beginning January 1,1998 . As a component of this system, APX is developing a green power exchange that will connect sellers and buyers of green power without the need for specific, bilateral contracts.

AllEnergy Marketing Company-In May 1997, AllEnergy Marketing Company, a joint venture formed by New England Electric System and Eastern Enterprises, announced the formation of a new division, $\operatorname{ReGen}^{\mathrm{SM}}$ Technologies, which plans to offer environmentally preferable electricity services. ReGen ${ }^{\mathrm{SM}}$ plans to facilitate the development of new renewable generation projects using clean technologies such as wind and solar to supplement existing regional resources.

Initially, ReGen ${ }^{\mathrm{SM}}$ products will be available to wholesale and retail customers in New England, where retail markets are expected to open in several states beginning in 1998. The company will target other markets nationwide as customer choice is adopted.

Edison Source-Edison Source, a subsidiary of Edison Enterprises, will offer Califomia customers an option of purchasing either half or all of their power from renewables, which will include solar, wind, small hydro, biomass, and geothermal resources. The $50 \%$ option will cost approximately the same as what customers pay for energy today, ${ }^{1}$ while those who choose $100 \%$ renewable energy will pay approximately $15 \%$ more, or about $2 \phi / \mathrm{kWh}$, depending on which company curently provides their electric service: In July 1997, Edison Source issued an RFP for suppliers of renewable electricity resources, requesting pricing and capacity information for renewables specified under guidelines issued by the Califormia Energy Commission (solar, wind, geothermal, small hydro, biomass, and landfill gas).

Electric Lite -Electric Lite, a South Carolina-based power company, announced that it will provide residential and commercial service in Portland General Electric's Customer Choice pilot, including "Electric Lite Green," a green power option. Foresight Energy will supply the green power that will be available to four Oregon cities at a premium of $1 \phi / \mathrm{kWh}$. The resource mix will consist of $26 \%$ existing geothermal, $25 \%$ new landfill gas, and $25 \%$ existing hydro, with the remaining $24 \%$ from natural gas, oil, coal, and nuclear resources.

Enron Energy Service-EES intends to provide end users with a broad range of energy choices at competitive prices. EES has successfully competed in selected retail natural gas and electricity

'By law, Califormia ratepayers are guaranteed a 10\% rate cut when direct access begins in 1998. 
marketing pilots, including the New Hampshire pilot. In Califomia, Enron is offering Earth Smart ${ }^{\mathrm{SM}}$ Power, which provides electricity containing $50 \%$ renewables, with the balance guaranteed not to come from coal, nuclear, or petroleum sources. Enron announced plans to build $39 \mathrm{MW}$ of new wind capacity in Southern Califomia that will provide electricity for Earth Smart ${ }^{\mathrm{SM}}$ Power.

In January, the City of Palm Springs announced the formation of Palm Springs Energy Services (PSES), an alliance between the City and FirstPoint California, a subsidiary of Enron. PSES will offer customers electricity service choices, including Enron's Earth Smart ${ }^{\mathrm{SM}}$ green power option.

Foresight Energy — Foresight Energy Company, based in Oakland, California, is a developer and wholesaler of "environmentally preferred electricity products." Foresight is assembling a portfolio of power purchase contracts with renewable and other clean generating facilities, and plans to bundle this supply with disclosure and other services to create a fully integrated product that it will sell to various electricity retailers. As of February 1998, Foresight reports that it has contracted to sell roughly $20 \mathrm{MW}$ of its Ecopower ${ }^{\mathrm{TM}}$ product, equivalent to approximately 25,000 residential users.

In September 1997, Foresight announced a working agreement with Northwest Environmental Advocates (NWEA), a Portland, Oregon-based environmental advocacy group, to develop its Ecopower ${ }^{\mathrm{TM}}$ electricity service for sale in the Pacific Northwest. Foresight plans to offer Ecopower ${ }^{\mathrm{TM}}$ to customers in Oregon, Califomia, Massachusetts, and Rhode Island through a number of electricity retailers.

Green Mountain Energy Resources-In August 1997, Vermont-based Green Mountain Power Corporation (GMP) and the Wyly Family of Texas announced the formation of a new company, Green Mountain Energy Resources (GMER), that will "create a retail brand of electricity and natural gas that will be sold to consumers who care about the environment in competitive markets across the nation." GMER has registered with the California PUC to be an electricity provider when the retail market opens to competition in 1998.

In October 1997, GMER announced a deal with Oregon-based PacifiCorp to be its first wholesale supplier of energy in Califomia. GMER's energy products will feature renewable energy, including small hydro, geothermal, and biomass power that PacifiCorp will supply. GMER and PacifiCorp will work together to identify environmentally sensitive energy sources for customers.

Also in October, GMER announced three electricity products for the California market:

- "75\% Renewable Power" will support renewables in Califormia and the West, including smallscale hydro, biomass, and geothermal resources. Three-fourths of the energy will come from qualifying renewables and $25 \%$ will come from large-scale hydro and system power. This service will cost customers about $11 \%$ more than buying from the electric utility in 1998 , or about the same as customers paid in 1997. ${ }^{2}$

\footnotetext{
${ }^{2}$ See Footnote 1.
} 
- "Water Power" is a power blend that will rely on $90 \%$ hydropower generated from a mix of large- and small-scale hydro facilities in Califomia and the West. The remaining $10 \%$ will come from system power. This option will cost $9 \%$ more than buying from the electric utility in 1998, or slightly less than customers paid in 1997.

- Wind for the Future ${ }^{\mathrm{SM}}$ will help build a market for construction of new wind turbines. One turbine will be built for every 3,000 customer subscribers. Power from the newly constructed wind turbines will account for $10 \%$ of the energy, with the remainder supplied by the " $75 \%$ Renewable Power" product. This option will cost customers, on average, about $\$ 11$ a month more than buying the standard electric utility service in 1998.

GMP is also a participating supplier in the New Hampshire electricity pilot program, offering customers a "green" electricity service consisting of $97 \%$ existing hydro (from Hydro Quebec), $1.5 \%$ natural gas, and $1.5 \%$ nuclear resources.

PacifiCorp-PacifiCorp is a registered energy service provider in California and has had two products certified by the Green-e program, but has made no announcements regarding retail green power offerings. PacifiCorp has an agreement to provide green power to Green Mountain Energy Resources for its California retail offerings and will be supplying green power to Clark Public Utilities beginning in March. A PacifiCorp subsidiary is also a registered service provider for the Pennsylvania retail access pilot, but has made no green power product announcements.

Working Assets Green Power-Working Assets Green Power (WAGP) is a retail power marketing company that has participated in both the New Hampshire and MECo retail access pilot programs. In both pilot programs, WAGP marketed its power as being non-coal, non-nuclear, and non-HydroQuebec. The company contracted with New England Electric System to provide its power supplies. The contract provides that WAGP purchase power from 11 specified power plants consisting of a mix of hydroelectric, oil-fired, and gas-fired generation. The company also donates $1 \%$ of its electricity income to environmental groups in each state.

WAGP registered as an energy service provider in Califormia but has decided not to offer a retail electricity service at the present time because they believe that the stranded asset provisions of the California restructuring law "stacks the deck against real competition." They also say that they have been unable to find a source of power that meets their environmental criteria. 


\section{Other Market News}

Corporation for Solar Technology and Renewable Resources-CSTRR is a not-for-profit corporation created to pursue solar power and other renewable resource development opportunities in Nevada and the Southwest. CSTRR's power market development strategy is aimed at federal facilities, public facilities, Native American Tribal councils, and various commercial customers. CSTRR has established an initial aggregate market target of 100 megawatts.

Green-e Program-A group of green power marketers has come together with a group of California consumer and environmental stakeholders to launch the country's first voluntary certification and verification program for environmentally preferred electricity products. The program's centerpiece-the Green-e logo-will help consumers easily identify products that contain at least $50 \%$ renewable electricity content.

To the extent that any fossil fuel resources are used, those resources must have air emissions per $\mathrm{kWh}$ for $\mathrm{SO}_{\mathrm{x}}, \mathrm{NO}_{\mathrm{x}}$, and $\mathrm{CO}_{2}$ less than or equal to the statewide system power mix. In addition, nuclear energy beyond that encompassed in system power may not be included.

Participating companies pledge to authenticate the renewable content of their electricity products, abide by a code of conduct governing their business practices, and provide customers with regular information about the sources of the electricity that they purchase. The first six power marketers to adopt the Green-e brand requirements are Edison Source, Enron Energy Services, Foresight Energy Company, Green Mountain Energy Resources, PacifiCorp, and Sacramento Municipal Utility District.

National Association of Attorneys General-Noting problems with defining what type of power can and should be labeled as "environmentally friendly," the NAAG announced that it will launch a task force to recommend language requiring disclosure when green power or marketing claims are used by electric utility providers. While taking no position on the environmental benefits of different types of power sources, the attorneys general emphasized that every state should ensure that consumers understand the exact nature of any green power marketing claims.

Natural Resources Defense Council-Based on an independent evaluation of the green power products currently being marketed in Califomia, the NRDC has identified four green power products as being environmentally preferable. The four products are: Enron's Earth Smart ${ }^{\mathrm{SM}}$ Power, Green Mountain Energy Resources' Wind for the Future ${ }^{\mathrm{SM}}$, and SMUD's Greenergy Community Solar and Renewable Energy Option, the latter two of which are only available in SMUD's service territory. NRDC notes that these four products "have substantially lower environmental impacts than the current California mix, and represent the 'greenest' power options currently available."

Renewable Energy Alliance — Six green power marketers have formed the Renewable Energy Alliance to pursue a common agenda to address regulatory issues and undertake market-building activities in support of green power. The founding members are Enron, Foresight Energy, Green Mountain Energy Resources, PacifiCorp, ReGen Technologies, and Edison Source. The group will work to support policies and regulations that establish fair market structures for environmentally 
preferable power sources and that foster the use of accurate environmental claims in the promotion of differentiated power products. 


\section{State Restructuring Policies for Renewables}

Although customer choice promises to encourage greater development of renewable energy sources through market-based mechanisms, many clean energy supporters argue that green power markets may be slow to develop. For example, in almost all states, utilities will be allowed to recover stranded asset costs for many years to come through a customer surcharge, delaying competitive market savings for most customers.

Another factor is the "public goods" component of electricity generation and environmental quality. That is, everyone is affected by the environmental damage caused by energy production, and conversely, everyone benefits when the system becomes cleaner. Those who choose to pay more for clean energy, in effect, subsidize those who don't.

For these reasons, many states have included polices to support some minimum level of renewables development during the transition to competitive electric markets. Eight of the 11 states that have passed electric power industry restructuring legislation have included policies for renewables. ${ }^{3}$ The different types of policies are briefly summarized below. Table 4 highlights the specific renewables provisions in state electricity restructuring laws.

\section{Renewables Portfolio Standard}

A renewables portfolio standard (RPS) sets a minimum renewable energy requirement for a state's electricity mix, under which every electricity supplier must provide some percentage of its supply from renewable energy sources. In some cases, a tradeable credit system is employed, under which electricity suppliers can buy and sell renewable generation credits in order to meet the requirement.

\section{System Benefits Charge}

A system benefits charge (SBC, also known as a public benefits charge) collects a non-bypassable fee from all electricity customers to fund public goods programs that may no longer be feasible for the utility to provide in a competitive electricity market. These programs include energy conservation, renewables, low-income assistance, and research and development.

\section{Green Marketing Incentives}

Only one state, California, has adopted incentives to directly encourage development of the green power market. After a lengthy public input and review process, the California Energy Commission decided to allocate a portion of the state's system benefits charge that will support renewables to a customer rebate account that "is designed to reduce the cost premium that customers pay for renewable energy and thus encourage customers to buy renewable power."

\footnotetext{
${ }^{3}$ We include Arizona in this group because the Arizona Corporation Commission, which has adopted rules for electric industry restructuring, is a constitutionally created regulatory body.
} 


\section{Information Disclosure}

One of the basic principles of efficient market operation is that consumers have adequate information to make educated purchase decisions. As a component of restructuring, states are considering requirements for uniform information disclosure that would provide consumers with objective information on the price and other important attributes of an electricity product or service, such as fuel mix and environmental emissions. Eight of the 11 states that have passed electric power industry restructuring legislation have adopted some type of provision for information disclosure. 
Table 4 - Renewables Components in State Restructuring Laws

\begin{tabular}{|c|c|c|}
\hline State & Mechanism & $\begin{array}{l}\text { Disclosure } \\
\text { Requirement }\end{array}$ \\
\hline Arizona+ & $\begin{array}{l}\text { RPS - solar portfolio requirement. Beginning in } 1999 \text {, all } \\
\text { participating electricity suppliers must obtain at least one-half of } \\
1 \% \text { of power sold competitively from a photovoltaic or solar } \\
\text { thermal source. The solar requirement increases to } 1 \% \text { in } 2002 \text {. }\end{array}$ & No \\
\hline California & $\begin{array}{l}\text { SBC }-\$ 540 \text { million over four years to fund a mix of production } \\
\text { incentives, project financing support, and customer rebates for } \\
\text { renewables. }\end{array}$ & Yes \\
\hline Illinois & $\begin{array}{l}\text { SBC }-5.0 \phi / \text { month surcharge on residential customers for } 10 \\
\text { years for renewables development fund; expected to raise } \\
\$ 5 \text { million per year. }\end{array}$ & Yes \\
\hline Maine & $\begin{array}{l}\text { RPS - } 30 \% \text { of retail sales to be provided by renewable } \\
\text { resources, including hydro, fuel cells, and municipal solid waste } \\
\text { in conjunction with recycling. } \\
\text { Also, voluntary fund for renewables R\&D. }\end{array}$ & Yes \\
\hline Massachusetts & $\begin{array}{l}\text { RPS - } 1 \% \text { of electricity sales from new renewables starting in } \\
2003, \text { rising by an additional } 0.5 \% \text { per year through } 2009 \text {, and } \\
\text { increasing to } 1 \% \text { each year thereafter. } \\
\text { SBC }-0.075 \phi / \mathrm{kWh} \text { from all customers, beginning in } 1998 \text {, to } \\
\text { support the development and promotion of renewable energy } \\
\text { projects. The charge increases to } 0.1 \phi / \mathrm{kWh} \text { in } 1999 \text { and } \\
0.125 \phi / \mathrm{kWh} \text { in } 2000 \text {, and decreases to } 0.1 \phi / \mathrm{kWh} \text { in } 2001 \text { and } \\
0.075 \phi / \mathrm{kWh} \text { in } 2002 \text {, and to a fixed } 0.05 \phi / \mathrm{kWh} \text { thereafter. }\end{array}$ & Yes \\
\hline Montana & $\begin{array}{l}\text { SBC }-2.4 \% \text { of } 1995 \text { utility revenues for energy conservation, } \\
\text { renewables, and low-income energy assistance. }\end{array}$ & Yes \\
\hline Nevada & $\begin{array}{l}\text { RPS }-0.2 \% \text { of total consumption, rising to } 1 \% \text { by } 2010 \text {, to be } \\
\text { obtained from in-state renewable resources (half of which must } \\
\text { come from solar power). }\end{array}$ & Yes \\
\hline New Hampshire & None & $\mathrm{No}^{\star \star}$ \\
\hline Oklahoma & None & No \\
\hline Pennsylvania & None & Yes \\
\hline Rhode Island & $\begin{array}{l}\text { SBC }-0.23 \phi / \mathrm{kWh} \text { for a minimum of five years to fund } \\
\text { renewables and demand-side management programs. }\end{array}$ & Yes \\
\hline
\end{tabular}

${ }^{\star}$ RPS = renewables portfolio standard; SBC = system benefits charge.

+Adopted by the Arizona Corporation Commission, a constitutionally created regulatory body.

**Under consideration 